\title{
Monitoring Changes in Cotton Acreage and Alternate Host Crops of Cotton Bollworm Using Remote Sensing and GIS in Major Cotton Growing Regions of India
}

\author{
Dharmesh Verma ${ }^{1}$, Manik H. Kalubarme ${ }^{2}$, G.P. Saroha ${ }^{3}$, K.S. Mohan ${ }^{4}$, K.C. Ravi ${ }^{4}$, Brajendra ${ }^{5}$ and A. N. Singh $^{6}$, \\ ${ }^{1}$ UPL Ltd., India \\ ${ }^{2}$ Space Applications Centre (ISRO) Ahmedabad, India \\ ${ }^{3}$ Computer Centre, MD University, Rohtak, India \\ ${ }^{4}$ MONSANTO Research Center, Bangalore, India \\ ${ }^{5}$ Indian Institute of Rice Research, ICAR, Hyderabad, India \\ ${ }^{6}$ Remote Sensing Applications Center, U.P., Lucknow, India \\ Email: verma.dharmesh@gmail.com, $\underline{\text { mhkalubarme@gmail.com }}$
}

\section{Commission III, WG III/10}

Key words: Alternative host crops, cotton bollworm, Helicoverpa armigera, Indian Remote Sensing Satellite (IRS) LISS-III, Crop proportions, Percent Tolerance Interval (PTI), Geographic Information System (GIS)

\begin{abstract}
:
Cotton cultivation has made rapid strides in India since the introduction of Bt cotton, which provided effective protection against its major pest, Helicoverpa armigera and other bollworms. The presence of alternate host crops for cotton bollworms targeted by $\mathrm{Bt}$ cotton play a key role in resistance evolution to the in planta expressed Bt proteins. Several host crops for $H$. armigera such as pigeonpea, sorghum, tomato, chilli, sunflower and corn are cultivated alongside Bt cotton. Change detection in the extent of cotton and alternate host crops of cotton bollworm was conducted using IRS LISS-III data in Punjab, Haryana, Rajasthan, Gujarat, Maharashtra, Andhra Pradesh and Karnataka states. The changes in the extent of cotton and host crops were monitored using multitemporal data of 2002, 2004 and 2008. The results indicated that Bt cotton (Hirsutum) has almost completely replaced the traditional Indian cotton (Gossypium arborium). Several alternate host crops of $H$. armigera were grown along with cotton. Pigeonpea was the major host crop in almost all the locations. Chilies dominated in Andhra Pradesh, sunflower in Karnataka and corn in Gujarat. These host crops serve as 'natural' refuge of $H$. armigera and possibly, for this reason this pest has not evolved resistance to the $\mathrm{Bt}$ expressed by Bollgard II even after 16 seasons of intensive cultivation; whereas the pink bollworm, a monophagous cotton bollworm, had developed resistance to Cry1Ac in 2009 and to Cry1Ac and Cry2Ab in 2015.
\end{abstract}

\section{INTRODUCTION}

\subsection{Status of cotton cultivation and importance of host crops in India}

Cotton covers an area of approximately 9 million ha in India representing about one quarter of the global area of 35 million ha under the crop. However, though the country ranks number one in area, it occupies third position in cotton production. India's average yield is only $319 \mathrm{~kg} / \mathrm{ha}$ lint as compared to the predominant bollworm on Indian cotton, causing $14-56 \%$ damage (Kaushik et al., 1969; Manjunath et al., 1989 and Jairaj, 1990). Fifty four percent of the total insecticides used on all crops in India are used on cotton and most of these are directed against $H$. armigera (Mohan and Manjunath, 2002). Genetically engineered cotton carrying an insecticidal protein, Cry1Ac, derived from the common soil bacterium Bacillus thuringiensis $(B t)$ has been developed against major cotton bollworms. These transgenics (Bt cotton) provide effective control of $H$. armigera and other bollworms such as the spotted bollworm, Earias vittella and pink bollworm, Pectinophora gossypiella. Bt cotton varieties have now been registered for commercial use in the United States, Australia, Mexico, Colombia, Argentina, China, India, South Africa and several other countries. Appropriate and judicious use of $B t$ cotton forms the most critical part in use of this technology. Development, implementation and execution of strategies to minimize the risk of target insect species like $H$. armigera developing resistance to the technology are mandatory world average of $603 \mathrm{~kg} / \mathrm{ha}$. Cotton is affected by several species of insect pests. Among the insects, Helicoverpa armigera (Hübner), the American bollworm, is a major pest of many economically important crops including cotton, pigeonpea, chickpea, sunflower, tomato, sorghum, millet, okra and corn (Manjunath, 1989; Sharma, 2001). These crops suffer extensive damage and the pest is difficult to control as it has developed resistance to several chemical insecticides. In particular, H. armigera is

in the direction of product stewardship. The resistance management strategy for $B t$ cotton is two-pronged: (1) effective control of target pests through season-long high levels of Cry1Ac expression in all important plant tissues, and (2) the provision of refuges of non- $B t$ plants where populations of susceptible target insects are generated to mate with any rare resistant insects that emerge from the $B t$ cotton. In countries where cotton is grown intensively on large, relatively homogeneous farms (such as the United States, Mexico and Argentina), farmers planting $B t$ cotton are also required to plant refuges of conventional cotton (USEPA, 2001). However, in smaller and multiple cropping systems, as in much of Asia and Africa, several other crop (other than cotton) species that can support the target pests of $B t$ cotton may be an important source of refuge inherent to these systems. If the target pests are utilizing a wide variety of these alternative host plant species, and they are not being controlled using $B t$ on these other hosts, then structured refuges for $B t$ crops may not be necessary under 
these conditions (Lin et al., 2014). In these cases, both cropping practices and the degree of polyphagy of the target insect species will be important (Wu et al., 2002, Khadi, et al. 2003; Kranthi and Kranthi, 2004; Green et. al., 2003; Ravi et al., 2005; Wu and Guo, 2005).

A study of the proportion of host crops, in time and space, in the cotton growing belt of India would help in better understanding of the population flux of Helicoverpa armigera on these crops during the cropping season. This information could also facilitate in evolving strategies for resistance management to $\mathrm{Bt}$ Cotton since it is grown now in significant area in the country.

\subsection{Remote Sensing and GIS Applications for Host Crop Mapping}

Satellite-based remote sensing has been widely used in agriculture for crop inventories and crop suitability analysis because of its advantages over traditional procedures in terms of cost effectiveness and time required for gathering information on large areas ((Navalgund et al. 1991, Zhu and Tateishi, 2000, Kalubarme et al., 2012)). The National Natural Resources Management System of India is using satellite remote sensing to procure information related to agriculture in India (Anon. 1989) including an inventory on multiple cropping in small land holdings. Kalubarme (2016) has used multi-temporal remote sensing, soil and agro-meteorological data in GIS environment for modelling cotton yield. As a widely used technology, remote sensing has become a reliable tool to obtain information on crop acreage, especially when multiple crops are cultivated in small holdings in adjoining fields (Sharma et al.,1994). This technology has been utilized in the present study to estimate the relative acreages of cotton and other host crops of $H$. armigera. Carriere et al (2005) have used GIS in Arizona to measure compliance with refuge requirement for $B t$ cotton in Arizona by mapping $B t$ and non- $B t$ cotton (refuge) based on refuge placement in the field and observed that compliance with reference to refuge cultivation was above $88 \%$ in five of six years.

\subsection{Major Objectives of the Study}

Major objectives of this study were:

i. To generate the spatial information about adjacency of host crops of Helicoverpa armigera in various cotton growing zones of India.

ii. To address intercropping of any other host crops with cotton.

iii. To study the change in the extent of host crops of Helicoverpa armigera during various cotton growing seasons especially during 2002, 2004 and 2008.

iv. To generate a GIS application to facilitate viewing adjacency between patches of alternate host crop.

\section{MATERIALS AND METHODS}

\subsection{Study Area Details}

Study area includes randomly selected rectangular blocks, one each in the sixteen districts in seven cotton growing states in the North, Central and South Zones of India. The states and districts selected in different zones are, North Zone: Punjab (Bhatinda, Ferozpur and Muktasar), Haryana (Sirsa) and Rajasthan (Sri Ganganagar), Central Zone: Gujarat (Bhavnagar and Rajkot) and Maharashtra (Akola, Nanded and Yeotmal), South Zone: Andhra Pradesh (Adilabad, Guntur and Warangal) and
Karnataka (Davangere and Raichur). The location map of study blocks in various states of India is given in Figure-1.
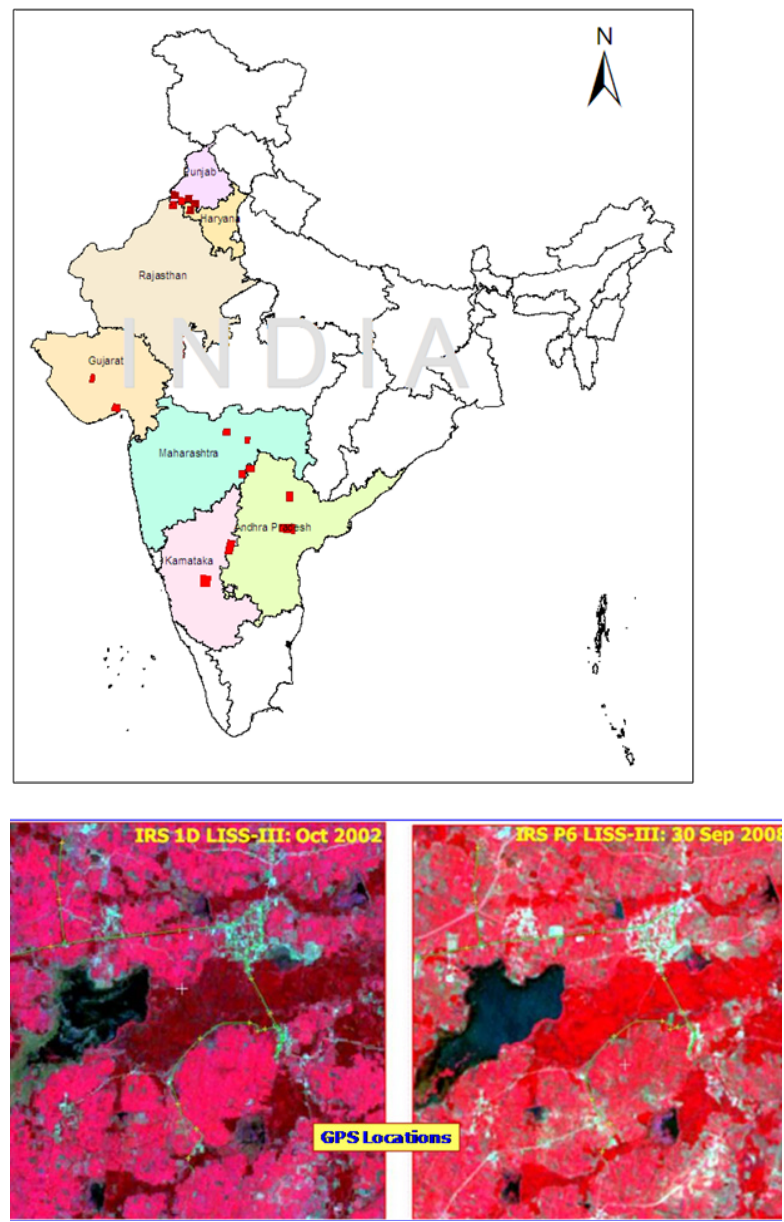

Figure 1. Location map of study areas in major cotton growing zones of India

\subsection{Indian Remote Sensing Satellite (IRS) data used}

Multi-temporal cloud-free digital data from Indian Remote sensing satellite (IRS-P6) LISS-III was acquired during Kharif Seasons (September-November), covering selected study districts in cotton growing states. Most of the IRS LISS-III data was acquired during the active vegetative and flowering stages of cotton during the months of September to November for different years (2002, 2004 and 2008).

\subsection{Collateral Data used}

Apart from the satellite data, the following other supporting data sets were used:

a) District/block boundary map from Census department and topographical maps from Survey of India.

b) Field data collected during extensive 'ground truth' verifications, including GPS observations.

c) Block-level statistics on different crops grown along with cotton and their relative proportions.

\subsection{Geo-referencing and Extraction of Study Area}

Image rectification and geo-referencing involves the removal of random and systematic errors of image and transforming image to UTM coordinate system in WGS84 datum. IRS LISS-III 
digital data

was registered using Ground Control Points (GCPs) identified on image and GPS measurements. Using these GCPs and GPS measurements, second order polynomials with nearest neighbor resampling procedure, the geo-referenced images were generated. Root Mean Square (RMS) errors of geo-referencing were within \pm 0.5 to 0.75 pixels for all the LISS-III images analyzed. Study area includes randomly selected rectangular blocks, one each in the listed sixteen districts stated above. Quadrant scenes of $25 \mathrm{~km} \times 25 \mathrm{~km}$, each were extracted from LISS III data of 2002, 2004 and 2008 cropping seasons for further analysis. Some the examples of LISS-III quadrants are shown in Figure-2.
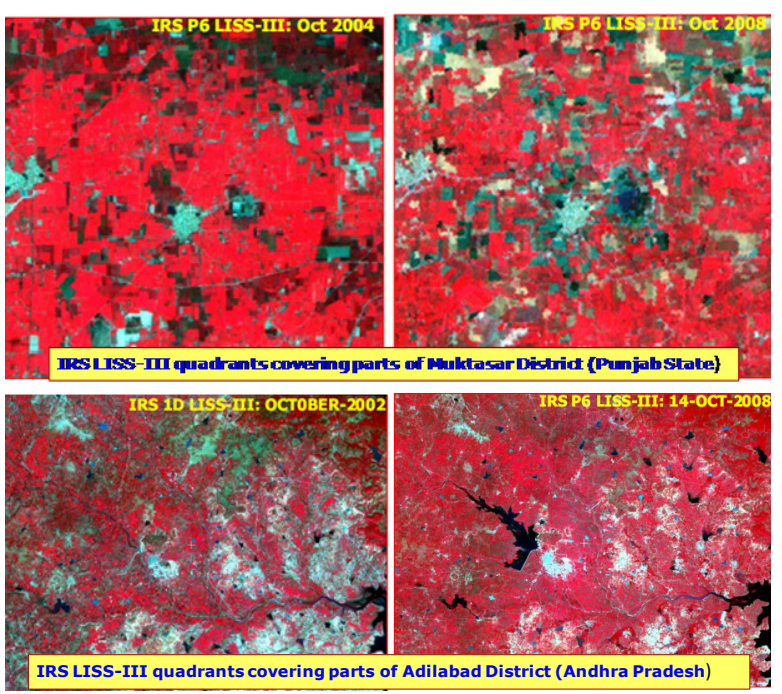

Figure-2: IRS LISS-III quadrants covering parts of Muktasar and Adilabad Districts

\subsection{Ground Truth Data Collection}

Ground truth / field verification is an important component in this project and utmost care and planning has been taken for ground data collection. During ground truth data collection, field details like type of crop, cropping pattern, various crops grown along with cotton, irrigation facilities, crop growth stages, crop health /condition were recorded in the ground truth Performa. The GPS measurements in various crop fields were also recorded for accurate field identification on the IRS LISSIII digital data. The GPS points collected in one of the districts along with traverse track is shown on IRS LISS-III data (Figure-3). The field photographs of some of the alternative host crops for $H$. armigera grown along with cotton in some districts are given in Figure-4.

\subsection{Generation of Training Signatures}

The False Colour Composite (FCC) of Quadrant scenes extracted from LISS-III digital data were used for identification of various crops and other land-use classes. Crops grown in different districts were identified on the FCC image based on the detailed GT data collected along with GPS measurements in each quadrant. Five-to-six classes with different developmental stages and percent ground cover having different vigour classes for each crop were identified for training signature generation. The training signatures contain multi-band statistics such as

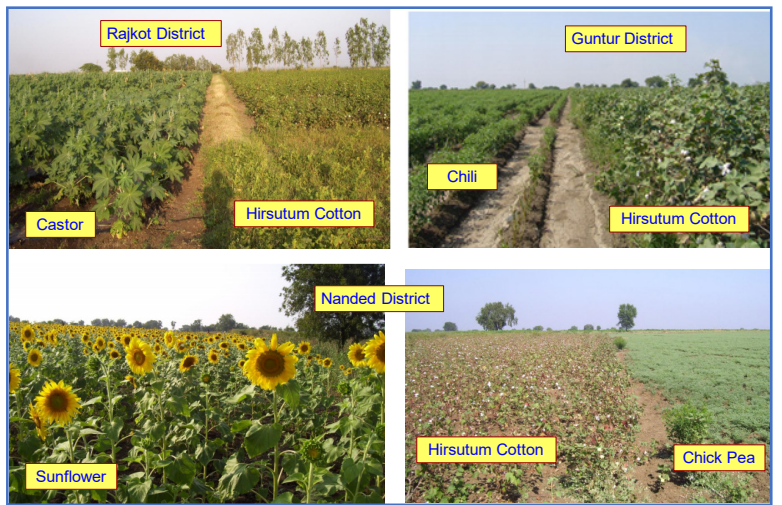

mean, standard deviation, and variance-covariance matrix for each class, which is used in supervised classification.

Figure-3 \& 4. IRS LISS-III images showing GPS point and track field Data collection

\subsection{Supervised Classification}

The LISS-III images of different quadrants were classified using Maximum Likelihood (MXL) classifier (Basham et al., 1997). The training signatures of various crops and other landuse classes generated from the Ground Truth (GT) sites were used for classification. The classified images were displayed and compared with FCC images to ascertain the unclassified pixels. The unclassified percentage acceptable in this study was 5 percent i.e. those pixels having less than $95 \%$ probability of belonging to any class were assigned to the reject class as unclassified pixels. From the supervised classified images, the crop maps of different quadrants were generated.

\section{RESULTS}

\subsection{Supervised Classification and Change detection}

The crop map for each quadrant of $25 \mathrm{~km}$ x $25 \mathrm{~km}$. One of the crop maps generated from classified quadrants of parts of Firozpur district, Punjab State is given in Figure-5.

\subsection{Crop mapping and Change Detection}

The change detection maps were generated from the classified images of 2004 and 2008 cropping seasons.

The area statistics of crops during 2004 and 2008 in Bathinda district, Punjab State is given in Figure-6. Some of the change detection maps covering part of the Firozpur and Bathinda districts, Punjab State, showing changes in cotton and other host crops are given in Figure-7 which indicates the range of host crops of H. armigera in these two blocks in Punjab State. The trend was similar in most of the blocks. The map and statistics show that the area under Hirsutum Cotton has increased significantly in 2008 and Arborium Cotton has negligible area in 2008 . 


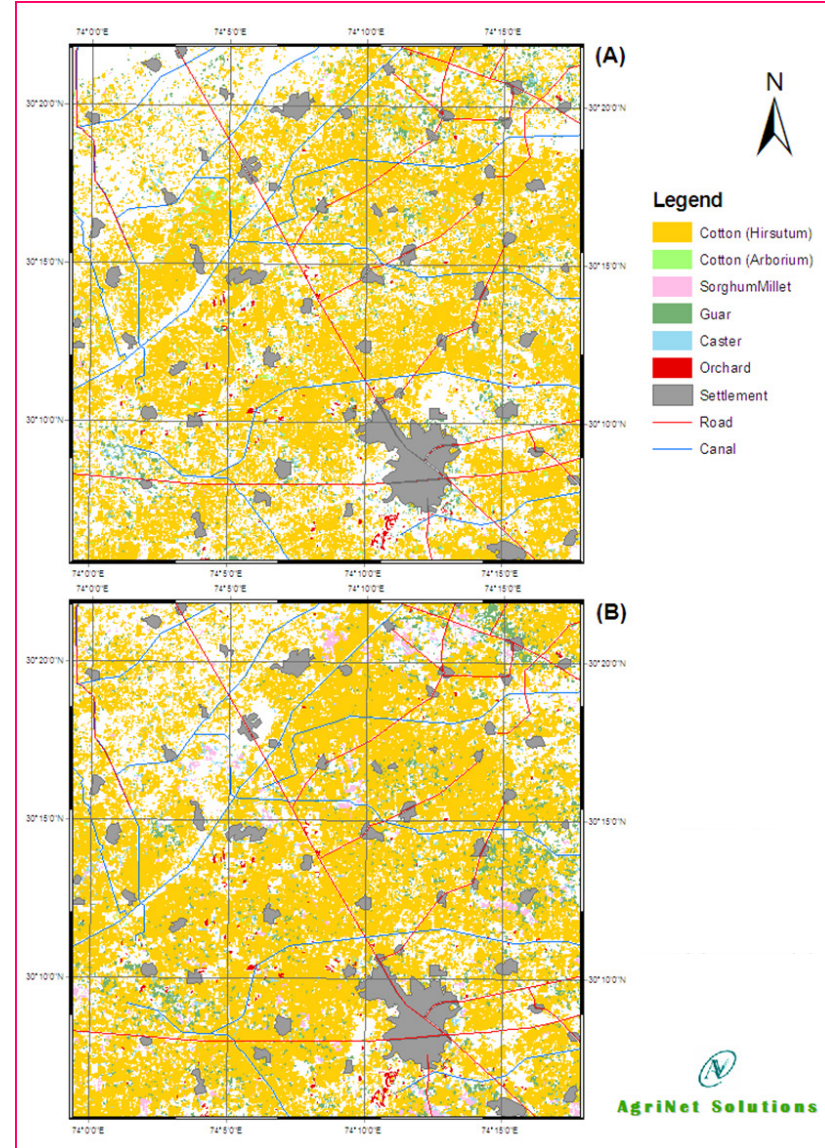

Figure-5. Crop maps for 2004 (A) and 2008 (B) of Firozpur district, Punjab

The mean acreage (ha) and percentage of area covered by each crop (of the total area occupied by cotton and the other host crops) in all the blocks is presented in Table-1.

3.2.1. Percent Tolerance Interval (PTI): To test the variability in proportion of crops, each block was subdivided into 25 sub-blocks ( $1 \mathrm{sq} \mathrm{km}$ each). Crop acreage and percent area covered by each crop was recorded in each sub-block. Mean values and percentages of crop acreages of various crops of 25 sub-blocks were computed and are presented in Table-1. Based on this table, Percent Tolerance Interval (PTI) for cotton and cotton - pigeon pea at 3:1 ratio was calculated (Table-2).

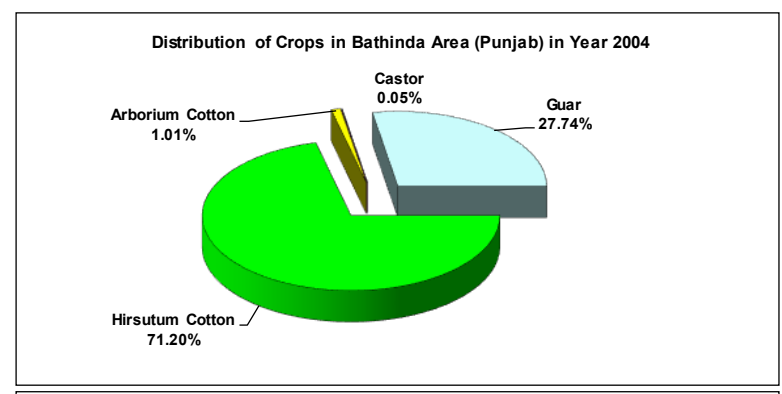

Distribution of Crops in Bathinda Area (Punjab) in Year 2008

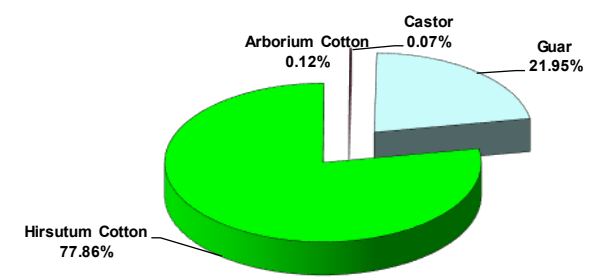

Figure-6. Distribution of Cotton and other crops in Bathinda during 2004 and 2008

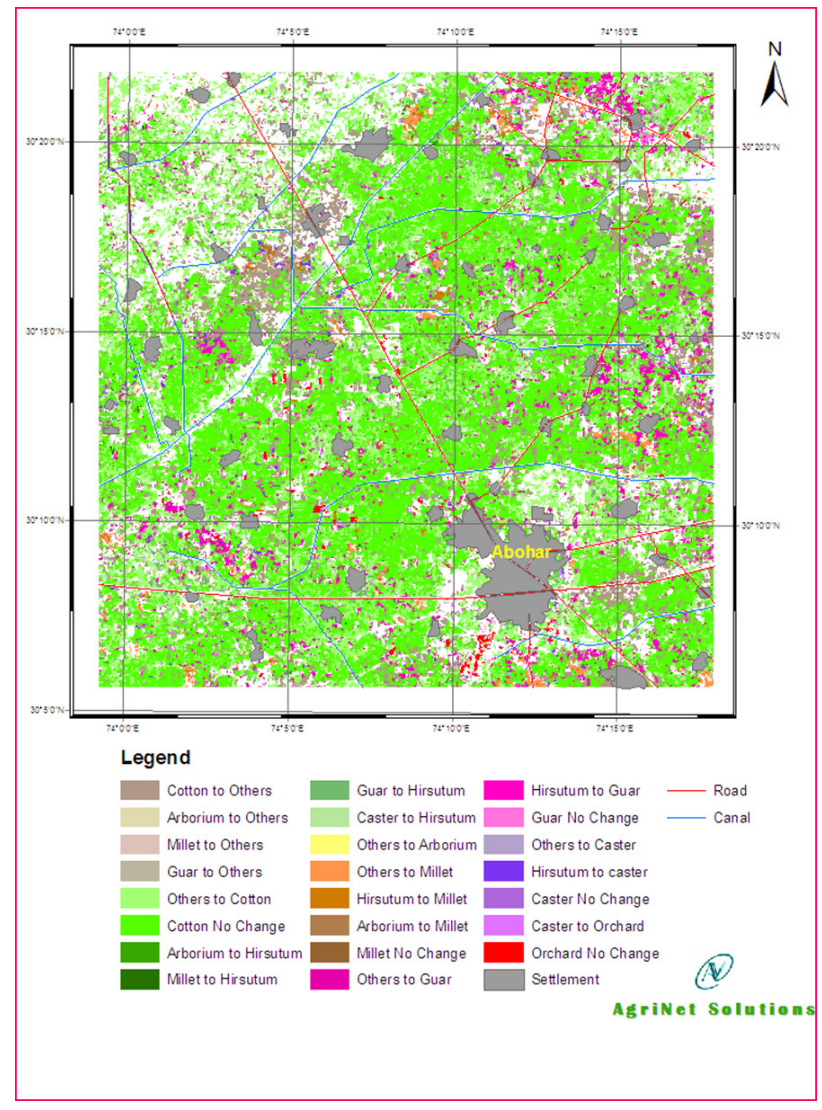

Figure-7. Change detection maps of parts of Ferozpur districts (Punjab State) 


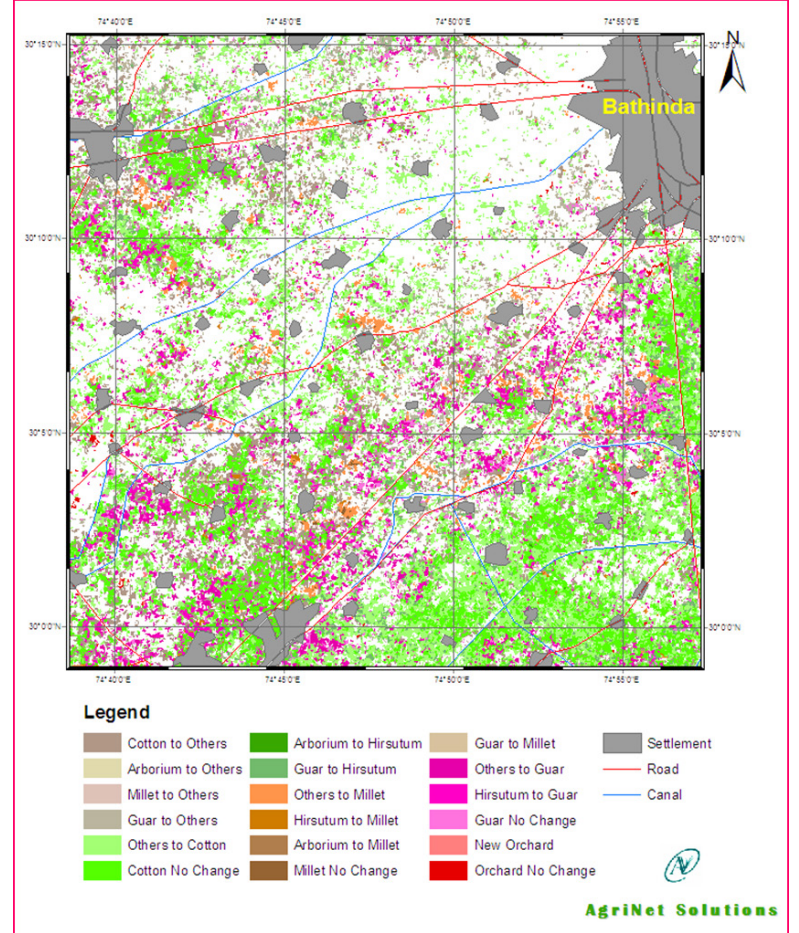

Agrinet Solutions

\begin{tabular}{|r|r|r|l|r|}
\hline Block & \multicolumn{2}{|c|}{ Cotton } & \multicolumn{2}{c|}{ Cotton + Pigeon pea } \\
\hline & \multicolumn{1}{l|l}{$\begin{array}{l}\text { Lower } \\
\text { PTI }\end{array}$} & Upper PTI & $\begin{array}{l}\text { Lower } \\
\text { PTI }\end{array}$ & Upper PTI \\
\hline 1 & 37.39 & 91.77 & & \\
\hline 2 & 66.73 & 98.83 & & \\
\hline 3 & 0.20 & 11.41 & 74.27 & 76.63 \\
\hline 4 & 0.45 & 8.39 & 28.07 & 60.26 \\
\hline 5 & 0.003 & 1.18 & 74.80 & 75.14 \\
\hline 6 & 0.18 & 13.94 & 27.50 & 81.73 \\
\hline 7 & 50.04 & 97.48 & 64.23 & 98.54 \\
\hline 8 & 37.76 & 73.28 & & \\
\hline 9 & 4.89 & 73.16 & & \\
\hline 10 & 15.11 & 84.14 & & \\
\hline
\end{tabular}

Table-2. Percent Tolerance Intervals (PTI) for cotton and cotton: pigeon pea (3:1) intercrop in western and southern zones

3.2.2. Accuracy of Crop maps: The overall accuracy levels (agreement between ground truth and imagery data) of mapping ranged from 82.4 (Block 10) to $98.9 \%$ (Block 5). The mean accuracy was $95.44 \pm 4.69$ (Mean $\pm \mathrm{SD}$ ).

3.2.3. Crop Mapping: The range of host crops along with cotton in different blocks was mapped. The mean area (ha) and percentage of area covered by each crop (of the total area occupied by cotton and the other host crops) in all the blocks is presented in Table-1. The details of area under cotton and various host crops in different blocks are as follows:

Figure-8. Change detection maps of parts of Bathinda districts (Punjab State)

\begin{tabular}{|c|c|c|c|c|c|c|c|c|c|c|c|}
\hline \multirow[b]{2}{*}{ Bhocks } & \multirow[b]{2}{*}{$\begin{array}{l}\text { Mean of } \\
\text { Sub blocks } \\
(\mathrm{n}=\mathbf{2 5})\end{array}$} & \multicolumn{10}{|c|}{ Crops } \\
\hline & & $\begin{array}{l}\text { Cotton + } \\
\text { Pigeonpea }\end{array}$ & Chilies & Cotton & Pigeonpea & Chickpea & Sunfikwer & Corn & Tomato & Okra & Total \\
\hline \multirow{2}{*}{$\mathbf{1}$} & Area (ha) & & 494.10 & 10847.70 & 3132.40 & & & 503.05 & 32.92 & & 15010.16 \\
\hline & Area $(\%)^{+}$ & & 3.73 & 68.35 & 23.64 & & & 4.01 & 0.25 & & 99.99 \\
\hline \multirow[t]{2}{*}{$\mathbf{2}$} & Area (ha) & & 160.83 & 27744.74 & 54.34 & & & 1165.78 & & & 29125.69 \\
\hline & Area $(\%)^{+}$ & & 1.07 & 90.94 & 0.36 & & & 7.63 & & & 100.00 \\
\hline \multirow[t]{2}{*}{3} & Area (ha) & 47113.52 & 31.16 & 1276.57 & 186.55 & 13.25 & 16.47 & & & & 48637.52 \\
\hline & Area $(\%)^{+}$ & 92.57 & 0.15 & 6.22 & 0.91 & 0.07 & 0.08 & & & & 100.00 \\
\hline \multirow[t]{2}{*}{4} & Area (ha) & 9025.69 & 104.58 & 504.59 & 3520.93 & & 458.48 & & & & 13614.27 \\
\hline & Area $(\%)^{+}$ & 66.30 & 0.01 & 3.71 & 2586 & & $\mathbf{3 . 3 7}$ & & & & 99.24 \\
\hline \multirow[t]{2}{*}{5} & Area (ha) & 22318.47 & 12.37 & 78.32 & 1789 & 4.06 & & & & & 22431.11 \\
\hline & Area (\%) ${ }^{+}$ & 99.41 & 0.06 & 0.40 & 0.09 & 0.03 & & & & & 99.99 \\
\hline \multirow[t]{2}{*}{6} & Area (ha) & 8638.19 & 2800.99 & 673.50 & 444.05 & & 1.94 & & & & 12562.44 \\
\hline & Area $(\%)^{+}$ & 68.76 & 22.30 & 5.36 & 3.53 & & 0.02 & & & & 100.00 \\
\hline \multirow[t]{2}{*}{7} & Area (ha) & & 4305.66 & 6756.16 & 1215.86 & & & & & & 12277.68 \\
\hline & Area $(\%)^{+}$ & & 35.58 & 54.30 & 10.22 & & & & & & 100.00 \\
\hline \multirow[t]{2}{*}{8} & Area (ha) & 2567.89 & 3209.65 & 21356.74 & & & & & 0.81 & 0.38 & 27135.47 \\
\hline & Area $(\%)^{+}$ & 12.47 & 15.49 & 72.02 & & & & & 0.004 & 0.002 & 99.99 \\
\hline \multirow[t]{2}{*}{9} & Area (ha) & & 959.81 & 2417.41 & 1265.16 & & 2399.96 & & & & 7042.34 \\
\hline & Area $(\%)^{+}$ & & 13.63 & 34_33 & 17.97 & & 34.08 & & & & 100.00 \\
\hline \multirow[t]{2}{*}{10} & Area (ha) & & 48.80 & 829.17 & 744.07 & & & & 9.31 & & 1631.35 \\
\hline & Area $(\%)^{+}$ & & 3.01 & 50.75 & 45.65 & & & & 0.57 & & 99.98 \\
\hline \multicolumn{12}{|c|}{$\begin{array}{l}\text { Each Block = } 25 \text { sq. } \mathrm{km} \text {; Each Sub-block = } 1 \mathrm{sq} . \mathrm{km} \text {, } \\
\text { Area }(\%)^{+}=\text {Percentage cropped area within the block }\end{array}$} \\
\hline
\end{tabular}

Table-1. Mean and percentages of crop acreages of various crops of sub-blocks 
Block 1 (Bhavnagar, Gujarat): Most of the area was covered by cotton $(68.35 \%)$, followed by pigeon pea $(23.64 \%)$. The area covered by corn, chili and tomato was $4.01 \%, 3.73 \%$ and $0.25 \%$ of the total, respectively. Wide range was observed in Percent Tolerance Interval for cotton with lower PTI of 37.39 and higher PTI of $91.77 \%$.

Block 2 (Rajkot, Gujarat): The cropping pattern in this block was similar to Block 1 with the largest area occupied by cotton $(90.94 \%)$. Area covered by other crops was negligible. PTI for cotton in this block was found to be high $(66.73-98.83 \%)$.

Block 3 (Akola, Maharashtra): The cropping pattern in this state was unique in the sense that area occupied by cotton as a sole crop was just $6.22 \%$, whereas the proportion of cotton and pigeon pea as intercrops dominated $(92.57 \%)$. Cotton was intercropped with pigeon pea at 5:2 to 8:3 (rows of cotton: pigeon pea) ratio. Pigeon pea as a sole crop was low $(0.09 \%)$, chili $(0.15 \%)$, sunflower $(0.08 \%)$ and chickpea $(0.07 \%)$. PTI for cotton ranged from $0.20-11.41 \%$ whereas for cotton - pigeon pea intercrop it varied from $74.27-76.63 \%$.

Block 4 (Nanded, Maharashtra): Similar to block 3, cottonpigeon pea intercrop occupied almost half the area $(66.30 \%)$, whereas the proportion under cotton alone was $3.71 \%$. In addition, pigeon pea as a sole crop occupied a substantial area (25.86\%). Sunflower occupied $3.37 \%$ followed by chili $(0.01 \%)$. Similar to block 3 , the PTI for cotton was low $(0.45-$ $8.39 \%)$ whereas for cotton - pigeon pea it ranged from $28.07-$ $60.26 \%$

Block 5: (Yeotmal, Maharashtra) - The cropping pattern was representative of the two other blocks in Maharashtra, with almost the whole area being cultivated with cotton - pigeon pea intercropping $(99.41 \%)$. The area under sole cotton was negligible $(0.40 \%)$, as for other sole crops like pigeon pea $(0.09 \%)$, chili $(0.06 \%)$ and chickpea $(0.03 \%)$. Lowest PTI was observed for cotton at this block $(0.003-1.18 \%)$ for cotton whereas PTI range was high and narrow for cotton - pigeon pea intercrop $(74.08-75.14 \%)$.

Block 6: (Adilabad, Andhra Pradesh) - Cotton-pigeon pea intercropping was dominant making up $68.76 \%$ of the area covered by cotton. It was followed by chili $(22.30 \%)$, cotton (5.36\%) and pigeon pea (3.53\%). Percent area under sunflower was negligible $(0.02 \%)$. PTI range was narrow and low for cotton $(0.18-13.94 \%)$ whereas wider and high range was noticed for cotton - pigeon pea intercrop $(27.50-81.73 \%)$.

Block 7: (Guntur, Andhra Pradesh) - Cotton, chili and pigeon pea were the major host crops grown in this location (Fig.7). Cotton alone occupied roughly half the area (54.30\%) among the host crops. It was followed by chili $(35.58 \%)$ and pigeon pea $(10.22 \%)$. Lower PTI for cotton and cotton - pigeon pea intercrop were $50.04 \%$ and $64.23 \%$, respectively. For both cotton and cotton - pigeon pea, upper PTI was high $(97.48 \%$ and $98.54 \%$, respectively.

Block 8: (Warangal, Andhra Pradesh) - Cotton was the single largest host crop occupying $72.02 \%$ of the total area among the host crops (Fig. 8). Chili covered $15.49 \%$, followed by cottonpigeon pea intercropping (12.47\%). Although, tomato and okra were grown, the area occupied by them was negligible. PTI for cotton varied from $37.76 \%-73.28 \%$.

Block 9: (Raichur, Karnataka) - In this location, cotton and sunflower occupied almost the same area (34.33 and 34.08\%, respectively. A substantial area was also covered by pigeon pea $(17.97 \%)$ and chili $(13.63 \%)$. Huge gap was noticed in PTI for cotton $(4.89-73.16 \%)$.

Block 10: (Bellary, Karnataka) - In general, the area covered for mapping was less in this particular location, so also the percent accuracy $(82.4 \%)$. Mean percent area wise, cotton and pigeon pea dominated the area $(50.75 \%$ and $45.65 \%)$ followed by low proportion of chilies $(3.01 \%)$. Similar to block 9 , huge variation was noticed in PTI for cotton $(15.11-84.14 \%)$.

3.2.4. Change Detection: Change in the area under cotton and other host crops of $\mathrm{H}$. armigera in the 16 districts of three zones has been presented as Table 3A (north zone), 3B (westcentral zone) and 3C (south zone). In some districts, year 2002 data was used instead of 2004 for comparison with 2008. The table shows that in the North Zone, area under Indian cotton has been replaced by Hirsutum $(\mathrm{Bt})$ cotton almost completely. In Bathinda, Firozpur and Mansa, area under cotton has increased, whereas in Muktsar, Sirsa and Shri Ganganagar, it has reduced and has been taken over by guar and sorghum. Guar and sorghum has increased in all the districts of this zone. Castor has also occupied more area in 2008, but its total extent is small. In the Western Zone (Bhavnagar and Rajkot), area under Hirsutum cotton has almost doubled during 2001- 2008. The area under sorghum as intercrop with cotton has reduced. Area under groundnut has also reduced significantly. Area under pigeon pea has more than doubled. Interestingly, sorghum is taken up as intercrop with cotton in Bhavnagar, while pigeon pea as intercrop in Rajkot.

In the Central Zone, the change detection between 2002 and 2008 showed that the area under Hirsutum (Bt) as sole crop has reduced in Nanded and Yeotmal districts and it has been taken over by cotton - pigeon pea intercrop, In Akola, Hirsutum cotton area has increased significantly $(226 \%)$ and the host crops - pigeon pea, chickpea, sorghum has also increased. The area under pigeon pea as intercrop with cotton has also reduced. In the South Zone, the change detection between 2002 and 2008 showed different trends in the study districts. In Adilabad and Warangal districts, the area under Hirsutum $(B t)$ cotton has reduced significantly. The area under pigeon pea as sole crop and as intercrop with Hirsutum also reduced in 2008. In these districts, cotton area has gone to other crops (rice), possibly due to increased irrigation facility in the area. In Guntur and Raichur districts, there is an increase in the area under Hirsutum as sole crop as well as intercrop with pigeon pea. In Guntur, area under chillies also increased by more than four times. This district is famous for the cultivation of chillies. In Raichur, area under sorghum and sunflower has reduced and taken over by chickpea. In Davangere, the change detection between 2002 and 2008 showed the area under Hirsutum as sole crop has reduced. On the other hand, corn/sorghum area as sole crop as well as intercrop with cotton has increased.

\section{DISCUSSION}

The present investigation has shown that area under Hirsutum (Bt) cotton has increased significantly in all the states and it has almost replaced traditional Indian cotton. Several host crops of $\mathrm{H}$. armigera are cultivated in fields adjacent to cotton, though the cropping pattern varied from region to region. Cotton as a sole crop was predominant in some parts of Andhra Pradesh and the whole of Gujarat (nearly 90\%). In Karnataka, percent area occupied by sole cotton ranged from $34-50 \%$, whereas in Maharashtra, cotton as a sole crop was rare (about 6\%), and 
cotton was almost always intercropped with pigeon pea at 5:2 to $8: 3$ (rows of cotton : pigeon pea) ratios. In two of the three blocks in Maharashtra, cotton-pigeon pea intercrops dominated, occupying $92-99 \%$ of the host crop area, whereas Nanded had $66.30 \%$ covered by the intercrop. Overall, pigeon pea was a common factor, either as a sole or intercrop, in all the blocks.

Apart from pigeon pea, chilli is also cultivated alongside cotton in almost all states. The proportion of chili was greatest in Andhra Pradesh (15 - 36\% of the area occupied by host crops) followed by Raichur in Karnataka (13.63\%). Its proportion in Gujarat was low (3.73\%) and negligible in Maharashtra. It is as attractive to $\mathrm{H}$. armigera as cotton and very likely a useful 'refuge' crop (Ravi et al., 2005). Sunflower was a major crop in Karnataka (34.08\%) and was grown on a small scale in parts of Andhra Pradesh and Maharashtra. Sunflower acreage has been seen to fluctuate over the years and currently it is very low. Corn is another potential 'refuge' crop in Karnataka and Gujarat, where its area is expanding rapidly.

Chickpea is another important crop for $\mathrm{H}$. armigera. Unlike on other crops, H. armigera starts its generation on the foliage of chickpea and later migrates to pods. Chickpea is cultivated in most parts of India as a rabi (winter) crop mostly toward the end of October. Satellite imagery indicated a negligible proportion of this crop in almost all states. Because the studies were carried out in September/ October, we believe that it was too early in the season to have substantial chickpea foliage growth recorded by the satellite sensor. It is likely that adult of $\mathrm{H}$. armigera emerging from fields of cotton and pigeon pea shift to chickpea to complete the next generation. Observations have shown that chickpea attracts more pest population as compared to other crop hosts in Australia (Miles and Fergusson, 2001) and India (Ravi et al., 2005). From this viewpoint, chickpea could be an important 'refuge' host in winter when no other major host crop is around.

Even though the proportion of host crops varied from region to region, it is unlikely that these proportions would change substantially over time because these cropping patterns are part of farmers' traditional practice. In Andhra Pradesh, all the host crops put together, barring cotton, occupied nearly $40 \%$ of the total area under host crops. In Karnataka, they covered 50\% of the total area. In Gujarat, the proportion of alternative host crops was less $(10 \%)$. Maharashtra presented a unique case where pigeon pea was cultivated as an intercrop with a substantial area, ranging from 66 to $99 \%$ the host-crop area. From an IRM perspective, this may not be ideal since there is a likelihood of mature larvae of $\mathrm{H}$. armigera moving over to $\mathrm{Bt}$ cotton from pigeon pea because of the close proximity of planting. Kranthi and Kranthi (2004) while discussing about modeling adaptability of $\mathrm{H}$. armigera to Bt cotton in India, mention that alternative host crops appear to play a major role in delaying resistance development compared to the conditions in Central India. However, from the present investigation it is evident that the availability of alternative host crops is similar both in Central and South Zones. In general, crop phenology in India ensures presence of five to six alternative hosts of the pest in any given part of the growing season (Manjunath et al. 1989; Khadi et al. 2003).

\section{CONCLUSIONS}

The results of the present study indicate that Hirsutum (Bt) cotton has almost replaced completely the traditional Indian cotton in all the states. It also indicated the utility of IRS LISSIII data in bringing out the cropping matrix prevalent in cottonintensive areas of small / medium holdings $(2-5$ acres) in these states. The Percent Tolerance Interval (PTI) indicates that proportion of cotton remains below $85 \%$ in seven out of 10 locations even under high cotton adoption in seven out of ten blocks. However, in two districts of Gujarat (Bhavnagar and Rajkot) higher cotton adoption by farmers could increase cotton area up to $98 \%$ with no room for alternative host crops. Since, in Gujarat both cotton varieties are grown, non-Bt cotton could serve as natural refuge. Similar adoption rate could be noticed in Guntur, Andhra Pradesh for cotton and also for cotton-pigeon pea intercrop. PTI, with reference to cotton-pigeon pea intercropping does not go beyond $80 \%$ under higher possibility of cultivation ensuring a minimum of $20 \%$ area under alternative host crops.

The results clearly indicate the presence of alternative host crops will serve as natural refuge thereby helping in insect resistance management. Similar agriculture system (multiple cropping and small holdings) is prevalent in China where field studies have demonstrated that many alternative host crops grown alongside cotton serve as natural refuge (Wu et al., 2002). Hence in China, structured refuge is not a mandatory requirement as natural refuge system is in operation and so far field resistance has not been noticed (Wu and Guo, 2005). In India also, H. armigera is known to feed on several weed hosts (Aherkar et. al., 1999). Further, non-Bt cotton will also serve as refuge for some of the insects like spotted bollworm, E. ariasvittella; spiny bollworm, E. insulana and pink bollworm, Pectinophora gossypiella. Concluding the general abundance of alternative host crops and the non-Bt cotton acreages should play the role of natural refuge in the years to come till there is drastic shift in cropping pattern based on economics or high adoption rate of $\mathrm{Bt}$ cotton in the major cotton belts of India.

The presence of significant area under alternate host crops also show that these crops serve as 'natural' refuge of $H$. armigera and possibly for this reason this pest has not evolved resistance to the $\mathrm{Bt}$ expressed by Bollgard II even after 16 seasons of intensive cultivation. Whereas the pink bollworm, a monophagous cotton bollworm, which can multiply only on cotton, had developed resistance to CrylAc in 2009 and to Cry1Ac and Cry2Ab in 2015. 
Table 3A. Northern Zone

\begin{tabular}{|c|c|c|c|c|c|c|c|c|c|c|}
\hline \multirow{3}{*}{ 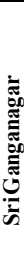 } & ○े & $\vec{\top}$ & 于 & $\vec{\Xi}$ & 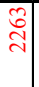 & 寸 & & & & \\
\hline & 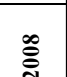 & $\begin{array}{l} \\
\dot{f} \\
\end{array}$ & $\hat{\infty}$ & $\stackrel{ \pm}{I}$ & $\begin{array}{l}\text { ลे } \\
\text { and }\end{array}$ & $\begin{array}{l}\text { నे } \\
\stackrel{\sim}{\sim}\end{array}$ & -7 & $\because$ & 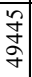 & 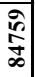 \\
\hline & ড্ডি & $\begin{array}{l}0 \\
\text { ô } \\
\text { n }\end{array}$ & 㐫 & 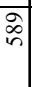 & ले & 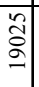 & 0 & & $\begin{array}{l}\text { a } \\
2 \\
\text { in }\end{array}$ & $\begin{array}{l}\text { â } \\
\frac{5}{5} \\
\infty\end{array}$ \\
\hline \multirow{3}{*}{ : } & ه & $\begin{array}{l}n \\
\vdots \\
1\end{array}$ & $\widehat{\Im}$ & ?ֶ. & $\vec{a}$ & $\frac{\square}{m}$ & নे & & & \\
\hline & 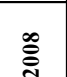 & $\begin{array}{l}m \\
\approx \\
=\end{array}$ & $\triangleright$ & $\stackrel{2}{2}$ & \begin{tabular}{l}
$\stackrel{2}{\curvearrowright}$ \\
\multirow{2}{\pm}{}
\end{tabular} & \begin{tabular}{l} 
\\
\multirow{2}{*}{} \\
0 \\
0
\end{tabular} & $\stackrel{\infty}{-\infty}$ & & $\begin{array}{l}\hat{n} \\
\tilde{q} \\
\tilde{f}\end{array}$ & 串 \\
\hline & 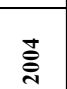 & 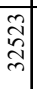 & ฉ̊ & 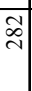 & $\overrightarrow{2}$ & $\underset{⿱ 亠}{\stackrel{J}{d}}$ & \pm & & 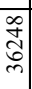 & 党 \\
\hline \multirow{3}{*}{ 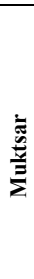 } & o & 寸 & $\stackrel{1}{~}$ & $\hat{a}$ & $\stackrel{2}{\infty}$ & $\begin{array}{l}m \\
\cong\end{array}$ & 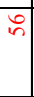 & & & \\
\hline & 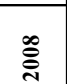 & $\begin{array}{l}\infty \\
\vec{\infty} \\
\infty\end{array}$ & 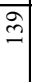 & $\stackrel{\tilde{0}}{=}$ & 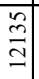 & 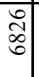 & $\begin{array}{l}\text { के } \\
\text { ( }\end{array}$ & 으 & 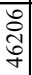 & $\begin{array}{l}2 \\
\stackrel{2}{7} \\
\infty \\
\infty\end{array}$ \\
\hline & 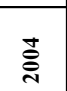 & $\begin{array}{l}\vec{n} \\
\stackrel{+}{n}\end{array}$ & $\begin{array}{l}0 \\
\dot{J} \\
\end{array}$ & $\vec{n}$ & $\begin{array}{l}\overrightarrow{\hat{n}} \\
\hat{\imath}\end{array}$ & $\begin{array}{l}\text { गे } \\
\text { ปे }\end{array}$ & $\stackrel{0}{-}$ & & 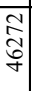 & $\begin{array}{l}20 \\
\frac{\pi}{\infty} \\
\infty\end{array}$ \\
\hline \multirow{3}{*}{ 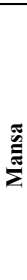 } & $\overbrace{}^{\circ}$ 总 & $\vec{a}$ & $\overrightarrow{7}$ & ते & 2 & $\begin{array}{l}\text { กै } \\
\text { - }\end{array}$ & $\exists$ & & & \\
\hline & 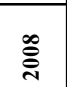 & 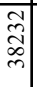 & $\checkmark$ & $\hat{\beth}$ & $\begin{array}{l}n \\
2 \\
2 \\
2\end{array}$ & $\vec{m}$ & $\begin{array}{l}\infty \\
\sim \\
\sim\end{array}$ & - & 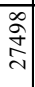 & 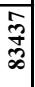 \\
\hline & ড্ডે & $\begin{array}{l}\tilde{O} \\
\stackrel{2}{2}\end{array}$ & $\div$ & 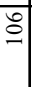 & 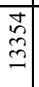 & $\hat{\infty}$ & $\begin{array}{l}0: \\
\text { i }\end{array}$ & & $\begin{array}{l}\overrightarrow{\text { f }} \\
\text { 守 }\end{array}$ & \begin{tabular}{c}
5 \\
\multirow{5}{\infty}{} \\
$\infty$
\end{tabular} \\
\hline \multirow{3}{*}{ : } & ه゚ & 2 & $\infty_{1}$ & $\dot{m}$ & $\stackrel{\infty}{+\infty}$ & $\bar{\delta}$ & 9 & & & \\
\hline & 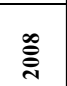 & \begin{tabular}{l}
0 \\
\multirow{b}{0}{} \\
$\stackrel{+}{+}$
\end{tabular} & 2 & $\vec{f}$ & $\begin{array}{l}\infty \\
\tilde{m} \\
\text { లి }\end{array}$ & 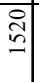 & $\begin{array}{c}n \\
\infty \\
n\end{array}$ & $\stackrel{\infty}{\sim}$ & $\begin{array}{l}\stackrel{\infty}{ \pm} \\
\stackrel{0}{\sim}\end{array}$ & $\begin{array}{l}\underset{\infty}{T} \\
\underset{\infty}{\infty}\end{array}$ \\
\hline & 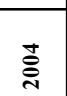 & 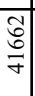 & ळे & $\stackrel{2}{\$}$ & $\begin{array}{l}\text { ते } \\
\text { ¿ेt }\end{array}$ & \begin{tabular}{l}
$\infty$ \\
\multirow{2}{0}{} \\
$\sim$
\end{tabular} & సี & & $\begin{array}{l}\text { aे } \\
\text { oे } \\
\text { bे }\end{array}$ & $\begin{array}{l}\mathbf{0} \\
\stackrel{\infty}{T} \\
\infty \\
\infty\end{array}$ \\
\hline \multirow{3}{*}{ 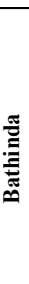 } & ๑̊ & $\stackrel{m}{m}$ & $\begin{array}{l}\overrightarrow{2} \\
\infty \\
1\end{array}$ & in & T & స్ & $\vec{\sim}$ & & & \\
\hline & 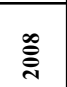 & 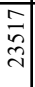 & 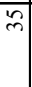 & त) & $\begin{array}{l}\text { 尺े } \\
\text { ర్రి }\end{array}$ & $\begin{array}{l}\tilde{N} \\
\text { V }\end{array}$ & 古 & $m$ & 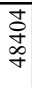 & $\begin{array}{l}\vec{T} \\
\stackrel{\infty}{\infty} \\
\infty\end{array}$ \\
\hline & 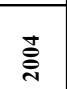 & $\begin{array}{l}\stackrel{2}{2} \\
\text { I } \\
=\end{array}$ & $\stackrel{+}{\sim}$ & 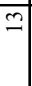 & $\begin{array}{l}\bar{n} \\
\hat{\sigma}\end{array}$ & $\hat{\mathrm{N}}$ & $\Xi$ & & 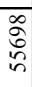 & 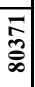 \\
\hline \multirow[t]{2}{*}{ Uે } & & 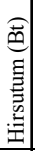 & 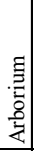 & 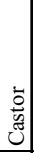 & 荧 & $\begin{array}{l}\text { 音 } \\
\text { 햄 } \\
\dot{0}\end{array}$ & 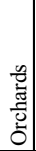 & 吾 & $\begin{array}{l}\frac{n}{ \pm} \\
\frac{ \pm}{0}\end{array}$ & ฮَّ \\
\hline & $\begin{array}{l}\dot{\vec{z}} \\
\dot{\boldsymbol{s}}\end{array}$ & -1 & $N$ & $m$ & $\nabla$ & in & 0 & $r$ & $\infty$ & \\
\hline
\end{tabular}

Table 3B. Western \& Central Zone

\begin{tabular}{|c|c|c|c|c|c|c|c|c|}
\hline & ○゚ & $\frac{0}{1}$ & f & $\frac{\pi}{T}$ & ปิ & $\begin{array}{l}\approx \\
\tilde{n} \\
\sim\end{array}$ & ता & \\
\hline 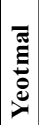 & $\stackrel{\infty}{\stackrel{\overbrace{}}{\sim}}$ & 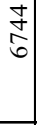 & $\begin{array}{l}n \\
+ \\
\infty \\
\infty\end{array}$ & $\begin{array}{l}\vec{n} \\
-\end{array}$ & $\begin{array}{l}\stackrel{0}{0} \\
\stackrel{\sim}{=}\end{array}$ & $\begin{array}{l}\hat{a} \\
n \\
n\end{array}$ & 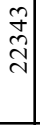 & 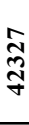 \\
\hline
\end{tabular}

Table3C.SouthernZone

\begin{tabular}{|c|c|c|c|c|c|c|c|}
\hline \multirow{3}{*}{ 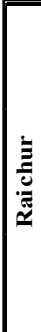 } & ○ & $\nabla$ & $m$ & $\infty$ & \begin{tabular}{l|}
9 \\
$\infty$ \\
1
\end{tabular} & $\begin{array}{l}\infty \\
7 \\
\end{array}$ & $n$ \\
\hline & $\begin{array}{l}\infty \\
\stackrel{\mathcal{~}}{\sim}\end{array}$ & 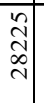 & 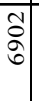 & 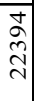 & $\begin{array}{l}\text { m } \\
\\
\end{array}$ & $\begin{array}{l}\infty \\
-1 \\
0\end{array}$ & $\begin{array}{l}n \\
\hat{n} \\
0 \\
0 \\
0\end{array}$ \\
\hline & $\underset{\mathcal{O}}{\overline{\mathrm{O}}}$ & $\begin{array}{l}8 \\
0 \\
\pm \\
0 \\
-1\end{array}$ & $\begin{array}{c}\stackrel{\circ}{N} \\
\stackrel{n}{n}\end{array}$ & \begin{tabular}{l}
\multicolumn{1}{c}{} \\
$\infty$ \\
$\infty$
\end{tabular} & $\begin{array}{l}n \\
\hat{b} \\
n \\
\end{array}$ & 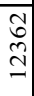 & $\begin{array}{l}\infty \\
\stackrel{2}{2} \\
2\end{array}$ \\
\hline
\end{tabular}

\begin{tabular}{|c|c|c|c|c|c|}
\hline ○ी & & ?ु) & 4 & \begin{tabular}{|c|} 
\\
$\ddots$
\end{tabular} & $\stackrel{\oplus}{\circ}$ \\
\hline$\stackrel{\infty}{\infty}$ & $\begin{array}{l}0 \\
n \\
m \\
-1\end{array}$ & & \begin{tabular}{|l|l}
$n$ \\
$\hat{b}$ \\
-
\end{tabular} & \begin{tabular}{|l|l|l|}
0 \\
$\dot{y}$
\end{tabular} & î. \\
\hline$\stackrel{\partial}{\partial}$ & $\mid$\begin{tabular}{|c}
$n$ \\
0 \\
0 \\
-1 \\
\end{tabular} & & 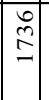 & $\mid$\begin{tabular}{|l|}
$\mid \vec{a}$ \\
|
\end{tabular} & $\begin{array}{l}\text { d } \\
\text { va }\end{array}$ \\
\hline
\end{tabular}

$\therefore$ 递

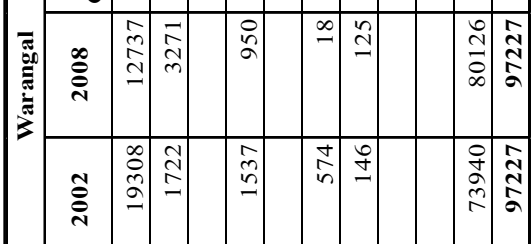

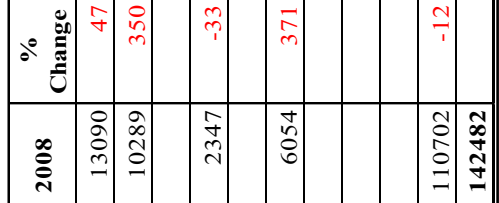

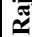

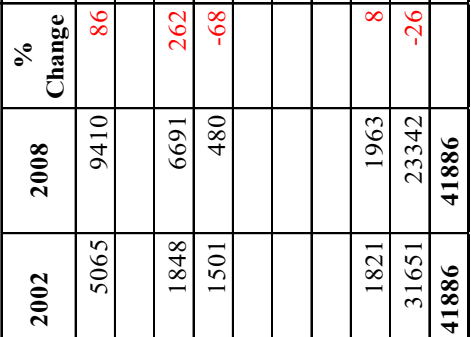

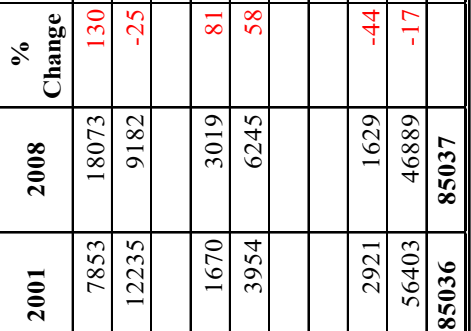

$\therefore$ 赵

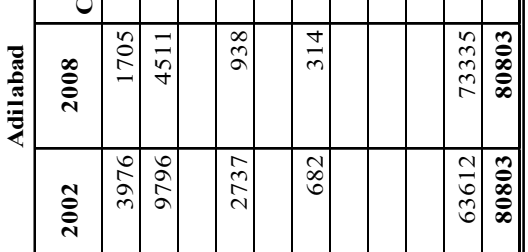

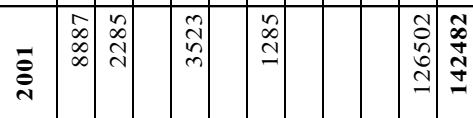

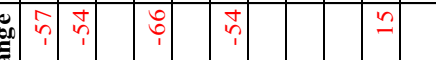

范

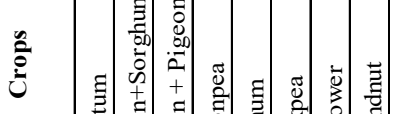

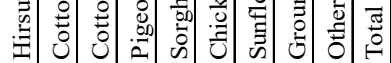

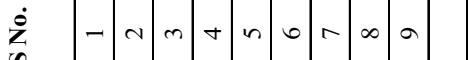




\section{REFERENCES}

Ahrekar, S.K., Nimbalkar,S. A., and Tikkar, S. N., 1999. Lagasceamollis - an alternate host for Helicoverpa armigera (Hub.). Insect Environment, 4, pp. 120.

Anonymous, 1994. Biological studies of H. armigera. Regional Agricultural Research Station. LAM Farm. Andhra Pradesh Agricultural University, India. pp. 25-28. Anonymous, 1989. Annual report. 1988-89. Department of Space, Government of India.

Basham May, A. M., Pinder III, J. E. and Kroh, G. C., 1997. 'A comparison of Landsat Thematic Mapper and SPOT multi-spectral imagery for the classification of shrub and meadow vegetation in northern California, USA, International J. Remote Sensing, 18 (18), pp. 3719-3728.

Carriere, K., Dennehy, T. J., Pedersen, B., Haller, S., Ellers-Kirk, C., Antilla, L., Liu, Y.B. Willott,E., Tabashnik, B.E., 2001. Large-scale management of insect resistance to transgenic cotton in Arizona: Can transgenic insecticidal crops be sustained? J. Econ. Entomol. 94 (2), pp. 315-325

Green, W. M., de Billot, M. C., Joffe,T., van Staden, L., Bennett-Nel, A. C., du Toit, L. N. and van der Westhuizen, L., 2003. Indigenous plants and weeds on the Makhathini Flats as refuge hosts to maintain bollworm population susceptibility to transgenic cotton (Bollgard). Afr.Entomol, 11, pp. 21-29.

Jairaj, S., 1990. The problem of Helicoverpa armigera in India and its integrated pest management. In: Heliothis Management. Proc. National Workshop, Centre for Plant Protection Studies, Tamil Nadu Agricultural University, Coimbatore. pp. 1-16.

Kalubarme, M.H., Chauhan, D.S. and Saroha, G.P., 2012. Cotton suitability analysis using Miles, M., and J. Ferguson. 2001. Trap-cropping: A fad or a useful Heliothis management tool. www.dpi.qld.gov.au/fieldcrops/6976.html.

Mohan, K.S., and Manjunath, T. M., 2002. Bt CottonIndia's first transgenic crop. J. Plant Biol, 29, pp. 225236.

Navalgund, R.R., Parihar, J.S., Ajai and Nageshwara Rao. 1991. Crop inventory using remote sensing data. Current Sci. $61(3,4)$, pp. $162-171$.

Ravi, K.C., Mohan, K.S., Manjunath, T.M., Head, G., Patil, B.V., Angeline Greba, D.P., Premalatha, K., Peter, J. and Rao, N.G.V., 2005. Relative abundance of Helicoverpaarmigera (Lepidoptera: Noctuidae) on different host crops in India and the role of these crops as natural refuge for Bacillus thuringiensis cotton. Environ Entomol. 34 (1), pp. 59-69.

Sharma, R.K., Sundara Sarma and Das, D.K., 1994. Crop discrimination in salt affected soils by satellite remote sensing.

http://www.gisdevelopment.net/aars/acrs/1994/ts1/ts1008p f.html. geoinformatics in Mansa district of Punjab state, India. Asian J. Geoinformatics 12 (4), pp. $27-36$.

Kalubarme M.H., 2016. Cotton yield modelling using multi-temporal remote sensing, soil and agrometeorological data in GIS environment. Ph. D. Thesis, Uttarakhand Technical University, Dehradun, India.

Kaushik, V.K., Rathode, V.S. and Sood, N.K. 1969. Incidence of bollworms and losses caused to cotton in Madhya Pradesh. Indian J. Entomol. 31, pp.175 - 177.

Khadi, B. M., Kulkarni,V. N., Katageri, I. S., Vamadevaiah, H. M. and Maralappanavar, M., 2003. Strengths, weaknesses, opportunities and threats analysis of Bt cotton in India. Paper presented at the World Cotton Conference, Cape Town, South Africa.

Kranthi, K.R. and Kranthi, N.R., 2004. Modelling adaptability of cotton bollworm, Helicoverpa armigera (Hubner) to Bt-cotton in India. Current Sci, 87(8), pp. $1096-1107$.

Lin Jin, Haonan Jhang, Yanhui Lu, Yihua Yang, Kongming Wu, Bruce E Tabashnik and Yidong Wu 2014. Large scale test of natural refuge strategy for delaying insect resistance to transgenic $\mathrm{Bt}$ Crops. Nature Biotechnology, 33, pp.169-174.

Manjunath, T.M., Bhatnagar, V. S., Pawar, C. S. and Sithanantham, S., 1989. Economic importance of Heliothis spp. in India and an assessment of their natural enemies and host plants, pp. 197 - 228. In: King, E. G. and Jackson, R.D. (Eds). Proc. Workshop on Biological Control of Heliothis: Increasing the effectiveness of natural enemies. 11-15 Nov. 1985, New Delhi, India. Far Eastern Regional Research Office, U.S. Department of Agriculture, New Delhi, India, $550 \mathrm{p}$.

Sharma, H.C. 2001.Cotton bollworm/Legume pod borer, Helicoverpaarmigera (Hubner) (Noctuidae: Lepidoptera): Biology and Management. Crop Protection Compendium. ICRISAT, Hyderabad, India, 72 p.

Wu, K.M. and Guo, Y.Y., 2005. The Evolution of Cotton Pest Management Practices in China. Annu. Rev. Entomol. 2005. 50:31-52

Wu, K., , Guo, Y. and Gao, S., 2002. Evaluation of natural refuge function for $\mathrm{H}$. armigera(Lepidoptera: Noctuidae) within Bacillus thuringiensis transgenic cotton growing areas in North China. J. Econ. Entomol. 95, pp. 832-837.

Zhu , L. and Tateishi, R., 2000. Integration of multi-sensor multi-temporal satellite data for agricultural vegetation mapping.

http://www.gisdevelopment.net/aars/acrs/2000/ps1/ps105 pf.htm 